\title{
The Development of Data Communications' Learning Media based Role Playing Game (RPG) at Vocational High School
}

\author{
Abdul Muis Mappalotteng \\ Faculty of Engineering \\ Universitas Negeri Makassar \\ Makassar, Indonesia
}

\author{
Purnamawati \\ Faculty of Engineering \\ Universitas Negeri Makassar \\ Makassar, Indonesia
}

\author{
Sri Wahyuningsih \\ Faculty of Engineering \\ Universitas Negeri Makassar \\ Makassar, Indonesia
}

\begin{abstract}
This study aims to produce the accurate, efficient and practical instructional media as a learning media based Role Playing Game (RPG) at SMK Telkom Makassar. In designing this learning media, the researchers used ADDIE development model which was modified to be ADDI. The resulting product development was the learning media of game-based RPG Maker VX ACE which is equipped with module and guideline's book. This development research was conducted on the subject of data communications at SMK Telkom Makassar. The students in XI class were the subject in this study consisting of 3 students for the one to one testing, ten students for the small group testing, 30 students for the field testing, and one educator and two observers for the field testing. The instruments used in collecting data were observation and questionnaire. The result is a strong, efficient and practical game-based RPG to be used as the learning instructional media for the subject of data communications at SMK Telkom Makassar. It was analysed using percentage narrative technique that was $\mathbf{8 5 . 0 1 \%}-\mathbf{1 0 0 \%}$ in the excellent category.
\end{abstract}

Keywords—media, game, RPG maker VX ACE

\section{INTRODUCTION}

Education is something that cannot be separated from human life. It continues to develop along with the development of science and technology. Therefore, it is essential to improve and enhance the education's quality. The supports to enhance the quality are human resources, learners, process, context, and the results of education itself. It shows that the main thing is human resources which are decisive in the term of teaching [1].

The education's quality assessment is usually associated with the learning achievement which is attained at each education's level. The success of teaching itself depends on several elements, and one of them is the teacher. Teachers are expected to develop skills in the teaching and learning process especially in the way they communicate to their students.

Teachers must be able to deliver the knowledge interestingly, so their students will feel interested and motivated.
Now everywhere in the current digital technology era, the learning process becomes more practical, and it is 'blurring the lines between media learning' further obvious than with the gaming practice and technology use. The coincide between current media and media interfaces are growing significantly as technologies of games and practices are growing pervasively. The development of information and technology (ICT) creates a learning media and learning process that becomes more attractive by using multimedia, including presentation's slides, film, animation video, and games [2][5].

Since the development of games, learning theory gains new inspiration by considering the educational game as a learning model [6], [7]. The game has a characteristic that can make players to be addicted. Therefore, it needs many creative innovations in creating the game as an instructional media that can be used in education to support teaching and learning activities and to attract the learners' motivation [8]. Moreover, fun learning is the learning process which there is a strong cohesion between teachers and students without being forced or have any pressured feeling [9]. Based on these descriptions, the researchers create an idea to build a new learning media by using computer technology, which is expected to create fun learning.

\section{RESEARCH METHOD}

This research was Research and Development, models which aim to build an interactive learning product in the form of a game. The game was applied to the Data Communications subject. The development model used in this research was the model of Analysis, Design, Development, Implementation, and Evaluation (ADDIE)

The research's subjects were the XI class students of Data Communications subject for Computer Engineering and Network Department at SMK Telkom Makassar. The sample of this research is the one to one or individual testing, small group testing, and field testing. The data subjects in this research were presented as follows: 
TABLE I. THE RESEARCh'S SUBJECTS

\begin{tabular}{|l|l|}
\hline \multicolumn{1}{|c|}{ The kind of Testing } & \multicolumn{1}{c|}{ The Number of Subjects } \\
\hline one to one testing & 3 students \\
Small Group Testing & 10 students \\
Field/Expanded Testing & 30 students \\
\hline
\end{tabular}

The data collection techniques in this research used interview, questionnaire, and test. The data obtained in this research were analysed by using the percentage descriptive technique [10].

The effectiveness of the RPG game based learning media for data communication is also seen from the students test results in 2015/2016 academic years. The RPG game based learning media of data communication can be stated to be effective if $80 \%$ of the students achieve the Minimum Completeness Criteria after completing the test [11]. The standard of Minimum Completeness Criteria that is used based on minimum Completeness Criteria for SMK Telkom Makassar is 2.67 (scale $1-4)$.

\section{RESULT AND DISCUSSION}

The development process of game-based learning media in this research was done in several stages which conducted based on ADDIE Model. The first stage deals with the investigation and collection of preliminary that were relevant to the learning media development. The second pace in this research was development step on the product format. After the planning was complete, then, the product was made. After the product had been designed, the validation test was conducted to the instruments used.

The third stage was the implementation of the product that had been revised based on the results of one-on-one or individual testing and small group testing. The tests were conducted on the bigger subjects. The collected quantitative data were analysed to obtain the data to be used to improve the product for repair at the next stage. Based on the evaluation of two experts' validation, it indicated that all instruments' components were stated valid. The revision was made based on the experts' advice, and the results were subsequently tested. The validation criteria consist of a learning plan, learning media, guidebooks, material, teachers' and students' instruments and response, and the achievement test.

In general, the testing results were eligible for a term of its practicality with the general assessment of all the components that have been validated by experts. Smith stated that the practicality level of game application is reviewed based on the questionnaire results which showed that the game is feasible to be published in general[12].

Based on the response that has been done by learners in three stages, namely the one-to-one testing involving three students, then followed by bigger samples which were ten students. They were given the opportunity to use the game that had been developed. Lastly, the field testing was conducted after completing the game application testing, and the application had been revised. It was applied to 30 people or close to the real learning condition. After conducting the testing on the XI class of TKJ for data communication's subject, students feel that the learning game is highly efficient and fascinating because the game has many challenges to solve a mission that is rewarded by knowledge. The educator's response was conducted by involving an educator of data communication subject. The educator was given questionnaire about the game based RPG Maker VX ACE. Furthermore, the result of educator's response was a very good category that is eight aspects scored four.

The testing results were likely effectiveness with the general assessment of all components that have been validated by experts. All validation experts gave the assessment which stated that all evaluation's components could be used with minimal revision. The learning media based RPG game of data communication was stated to be effective if $80 \%$ of the students test score to achieve the Minimum Completeness Criteria [11]. The standard of Minimum Completeness Criteria that is used based on minimum Completeness Criteria for SMK Telkom Makassar is 2.67 (scale $1-4$ ). Based on this criterion, it can be concluded that the learning media-based game has been effective to be used because the students' achievement scores have been qualified with the standard of Minimum Completeness Criteria.

Two observers conducted the observation of the effectiveness regarding the teacher's activity towards the Game based RPG Maker VX ACE. Van Merriënboer \& Kirschner (2012) explained that the range percentage of the instrument could be stated to be very active or feasible if the acquired score is $85.01 \%$ - $100 \%$. Based on this criterion, it can be said that it was adequate for all teacher's activities for four meetings. It showed the significant improvement from the average of $83 \%, 87 \%, 98 \%$, and $99 \%$ which showed the average category of very active. In term of students' activity, it can be concluded that the students' activities for four meetings were adequate which showed the significant improvement from the average of the very active category.

Quality learning depends heavily on student motivation and lecturer creativity. Students who have high motivation supported by lecturers who can facilitate the motivation will lead to the achievement of learning targets. Learning targets can be measured through changes in students' attitudes and abilities through learning. Good learning design, supported by adequate facilities, coupled with the creativity of lecturers will make students more easily achieve the target learning. The success in teaching and learning requires the ability of lecturers in planning, which includes among others determining student learning objectives, how to make the students achieve the goal, what means required, as a system or learning process [14]-[16].

Learning is a process that can develop students' potentials in a holistic and integrated manner [17]. The development of individual dimensions partially will not be able to support the optimisation of potential student development as expected. Therefore, in the process of learning, lecturers are not only required to deliver teaching materials but must be able to actualise its strategic role in the effort to shape the character of students through the development of personality and values that apply. 


\section{CONCLUSION}

The analysis, of this research, referred to need analysis determining the problem, the appropriate solution and the learners' competence. The designs of this research focused on defining specific competencies, methods, materials, and strategies for learning media. The development step referred to developing of game learning media. The last stage is implementation, deals with the implementation of learning program media. The media learning development produced the instructional learning media using Role Play Game produce a data communication subject for Network Computer Engineering and Guidebook/module. The product resulted in the form of learning game has been valid, efficient and practical to use as a learning medium for data communication subject

\section{REFERENCES}

[1] P. W. Glewwe, E. A. Hanushek, S. D. Humpage, and R. Ravina, "School resources and educational outcomes in developing countries: A review of the literature from 1990 to 2010," National Bureau of Economic Research, 2011

[2] C. Dede, "Theoretical perspectives influencing the use of information technology in teaching and learning," Int. Handb. Inf. Technol. Prim. Second. Educ., pp. 43-62, 2008.

[3] A. Kirkwood and L. Price, "Learners and learning in the twenty- first century: what do we know about students' attitudes towards and experiences of information and communication technologies that will help us design courses?," Stud. High. Educ., vol. 30, no. 3, pp. 257-274, 2005.

[4] A. Sife, E. Lwoga, and C. Sanga, "New technologies for teaching and learning: Challenges for higher learning institutions in developing countries,"Int. J. Educ. Dev. using ICT, vol. 3, no. 2, 2007.

[5] S. Livingstone, "Media literacy and the challenge of new information and communication technologies," Commun. Rev., vol. 7, no. 1, pp. 314, 2004.

[6] J. Torrente, Á. Del Blanco, E. J. Marchiori, P. Moreno-Ger, and B. Fernández-Manjón, “< e-Adventure >: Introducing educational games in the learning process," in Education Engineering (EDUCON), 2010 IEEE, 2010, pp. 1121-1126.

[7] V. J. Shute, L. Rieber, and R. Van Eck, "Games... and... learning," Trends issues Instr. Des. Technol., vol. 3, 2011.

[8] M. F. Young, S. Slota, A. B. Cutter, G. Jalette, G. Mullin, B. Lai, Z. Simeoni, M. Tran, and M. Yukhymenko, "Our princess is in another castle a review of trends in serious gaming for education," Rev. Educ. Res., vol. 82, no. 1, pp. 61-89, 2012.

[9] R. J. Wlodkowski, Enhancing adult motivation to learn: A comprehensive guide for teaching all adults. John Wiley \& Sons, 2011.

[10] M. G. Lodico, D. T. Spaulding, and K. H. Voegtle, Methods in educational research: From theory to practice, vol. 28. John Wiley \& Sons, 2010

[11] R. Widyatiningtyas, Y. S. Kusumah, U. Sumarmo, and J. Sabandar, "The impact of problem-based learning approach to senior high school students'mathematics critical thinking ability," J. Math. Educ., vol. 6, no. 2, pp. 107-116, 2015.

[12] D. Smith, "Distance learning: A game application," Dev. Bus. Simul. Exp. Learn., vol. 37, 2014.

[13] J. J. G. Van Merriënboer and P. A. Kirschner, Ten steps to complex learning: A systematic approach to four-component instructional design. Routledge, 2012.

[14] R. B. Barr and J. Tagg, "From teaching to learning-A new paradigm for undergraduate education," Chang. Mag. High. Learn., vol. 27, no. 6, pp. 12-26, 1995.

[15] J. B. Biggs, Teaching for quality learning at university: What the student does. McGraw-Hill Education (UK), 2011.

[16] G. Nicholls, Developing teaching and learning in higher education. Psychology Press, 2002.

[17] M. S. Poplin, "Holistic/constructivist principles of the teaching/learning process: Implications for the field of learning disabilities," J. Learn. Disabil., vol. 21, no. 7, pp. 401-416, 1988 . 